\title{
Microwave Remote Sensing of Water Vapor in the Atmosphere
}

\author{
Niklaus Kämpfer, Beat Deuber, Dietrich Feist, Daniel \\ Gerber, Christian Mätzler, Lorenz Martin, June Mor- \\ land, Vladimir Vasic, Berne
}

\section{Introduction}

For a long time greenhouse warming and the depletion of the ozone layer have been studied as two independent problem areas. It has been thought that the stratosphere with only about $10-20 \%$ of the atmosphere in terms of mass can play only a limited role in climate change. However, there has been increasing evidence in recent years that the stratosphere is a sensitive component of the climate system, which can affect the troposphere through various coupling mechanisms: such as radiative transfer, changing the characteristics of tropospheric waves by affecting the upper boundary condition of the troposphere or through the downward propagation of zonal-mean anomalies (SHEPHERD 2000). A detailed understanding of the processes by which atmospheric composition affects climate directly, through the distributions of water vapor, other greenhouse gases and aerosols, and indirectly through chemistry and vice versa is thus vital in order to predict the future state of the atmosphere. A summary of the latest findings in the field of global change is given in the reports of the INTERGOVernmental Panel on Climate Change (IPCC) (2001) on climate change and in the World MeteorologiCAL Organization (WMO) (1998) assessments of the ozone layer. Both are updated at regular intervals. Ozone and water vapor play key roles in the subject under discussion.

Water vapor plays a crucial role in atmospheric processes through its radiative, chemical and dynamical properties. In the upper troposphere it is one of the main greenhouse gases that absorbs longwave terrestrial radiation. Its distribution is strongly influenced by both large scale circulation and localized convection. Chemically, water vapor is a major source of the hydroxyl radical, the primary oxidant in the troposphere that is able to react with most pollutants. Water vapor is also a valuable tracer of atmospheric motion due to its long chemical lifetime. Part of water vapor enters the stratosphere by vertical transport in the tropical tropopause with the air being freeze dried by the low tropopause temperature and spreads to middle latitudes with a certain phase lag. Air passing this way through the tropopause and carried upward through the large scale circulation is marked by the mixing ratio of entry in the same way as a magnetic tape recorder is marked by the recording head. This effect that is clearly visible has been called atmospheric tape recorder (MoTE et al. 1996). In addition, $\mathrm{H}_{2} \mathrm{O}$ in the stratosphere is produced by oxidation of $\mathrm{CH}_{4}$. Both sources contribute approximately one half to the available water vapor in the middle atmosphere. The sink of $\mathrm{H}_{2} \mathrm{O}$ in the middle atmosphere is photolysis. While the methane oxidation is well understood, understanding of tropical stratospheretroposphere exchange is weak. More insight in these processes might be obtained by observations of the isotopic content of water entering the tropical stratosphere as the saturation vapor pressure of isotopes heavily depends on temperature (KeITH 2000). However, only very few measurements of water isotopes exist. Another unsolved issue in atmospheric water vapor is the discovery of a narrow layer of $\mathrm{H}_{2} \mathrm{O}$ located at approx. $70 \mathrm{~km}$ altitude in the mesosphere where the $\mathrm{H}_{2} \mathrm{O}$ mixing ratio reaches the highest values observed in the middle atmosphere (Summers et al. 1997). This layer can only be explained by a local source of $\mathrm{H}_{2} \mathrm{O}$. Suggestions have been made that this layer could be produced by an influx of small comets releasing water in the atmosphere. However, Summers \& SisKIND (1999) propose a recombination of $\mathrm{O}$ and $\mathrm{H}_{2}$ on meteoric dust as this source of mesospheric water vapor.

Measurements of water vapor in the upper troposphere and in the stratosphere require an enormous technical effort due to large gradients around the tropopause and the stratospheric mixing ratios of a few ppmv in contrast to the moist tropospheric air masses. In addition, in the stratosphere, the spatial and temporal variability of the $\mathrm{H}_{2} \mathrm{O}$ abundance is relatively small, i.e. changes of a few tenths of 1 ppmv need to be detected with a similar accuracy of the measurement. No single instrument today is capable of $\mathrm{H}_{2} \mathrm{O}$ measurements at all altitudes, with adequate global and temporal coverage. Therefore a combination of different techniques is necessary in order to investigate the spatial and temporal variability of water vapor. In situ measurements are mainly limited to altitudes below approx. $35 \mathrm{~km}$ and are performed on balloons or from aircraft, which are restricted by set cruising attitudes. Signatures of tropospheric and stratospheric exchange have e.g. been studied in this way by Ovarlez et al. (1999). A method that is particularly well suited to investigate the vmr-profile from the ground is microwave radiometry that retrieves the profile from pressure broadened transition lines. Measurements of water vapor in the middle atmosphere have successfully been performed e.g. by NED- 
$\mathrm{H} 2 \mathrm{O}$ Spectra at $183.31 \mathrm{GHz}(11 \mathrm{~km}$ alt.) measured by AMSOS

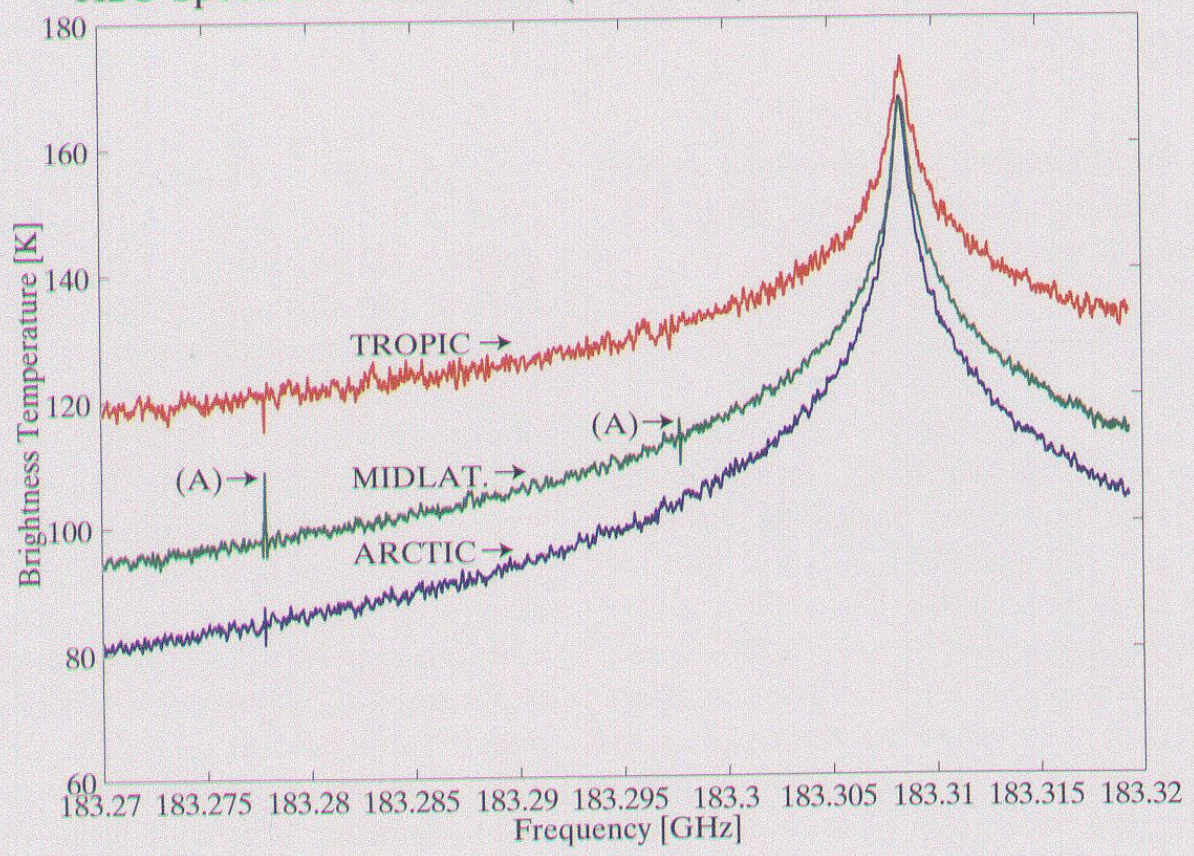

Fig. 1: Measured spectra of the water vapor transition at $183.310 \mathrm{GHz}$ from different latitudes. Higher values in the wings indicate higher values of water vapor at the flight altitude of approx. $11 \mathrm{~km}$ which is particularly true for the subtropics where the tropopause is higher.

Gemessene Spektren der Wasserdampflinie bei $183.310 \mathrm{GHz}$ für verschiedene geographische Breiten. Höhere Werte in den Flügeln der Spektrallinie weisen auf eine höhere Wasserdampfmenge in einer Flughöhe von $11 \mathrm{~km}$ hin. Dies trifft insbesondere für die Subtropen zu, wo die Tropopause oberhalb der Flughöhe liegt.

Spectre de la ligne de transition de la vapeur d'eau à $183.310 \mathrm{GHz}$, mesuré à différentes latitudes. Des valeurs élevées sur les flancs de la ligne indiquent de plus grandes quantités de vapeur d'eau présentes à l'altitude de vol d'environ $11 \mathrm{~km}$. C'est le cas en particulier pour la région subtropicale, où l'altitude de la tropopause est plus élevée.

OLUHA et al. $(1997,1998,1999)$, who observed a clear annual cycle and an upward trend in middle atmospheric water vapor of $0.15 \mathrm{ppmv} / \mathrm{yr}$ in the altitude range of $40-60 \mathrm{~km}$ concluding that there has been a significant increase in the amount of water vapor entering the middle atmosphere. However, the exact cause is unknown. Seele \& Hartogh (1999) observed with microwave radiometry a pronounced annual cycle of water vapor in the polar middle atmosphere that is stronger than what has been reported for midlatitudes. A more global coverage of data has been obtained by different satellite sensors e.g. LIMS, ATMOS, HALOE and MLS. A climatology of water vapor mixing ratios for October 1991 - June 1997 was presented from the microwave limb sounder (MLS) on UARS (Upper Atmosphere Research Satellite), by STONE et al. (2000). An assessment of the present state of knowledge can be found in the SPARC (Stratospheric Processes And their Role in Climate) report on upper tropospheric and stratospheric water vapor (SPARC 2000).
Research in tropospheric water (mainly water vapor, but also cloud liquid and frozen water) has increased in recent years due to its importance for processes relevant to radiation, meteorology, climate, hydrological cycles, biogeochemistry and human activities, such as telecommunications. One handicap in this research has not been removed so far, namely the lack of accurate methods to measure atmospheric humidity. The large errors observed for water vapor soundings is certainly affected by the heterogeneity and temporal variability of water in the atmosphere. But this is not the only reason for the problem. Most measurement methods rely on comparisons with radiosonde data. That widely used humidity sensors on radiosondes can have more significant errors than was expected so far, was recently demonstrated by WESTWATER et al. (2000) for the Vaisala Humicap RS80 sensor. Although correction algorithms for aging can reduce the errors, they cannot be removed effectively.

In order to address these open questions and uncertainties in our knowledge of water vapor, high quality 


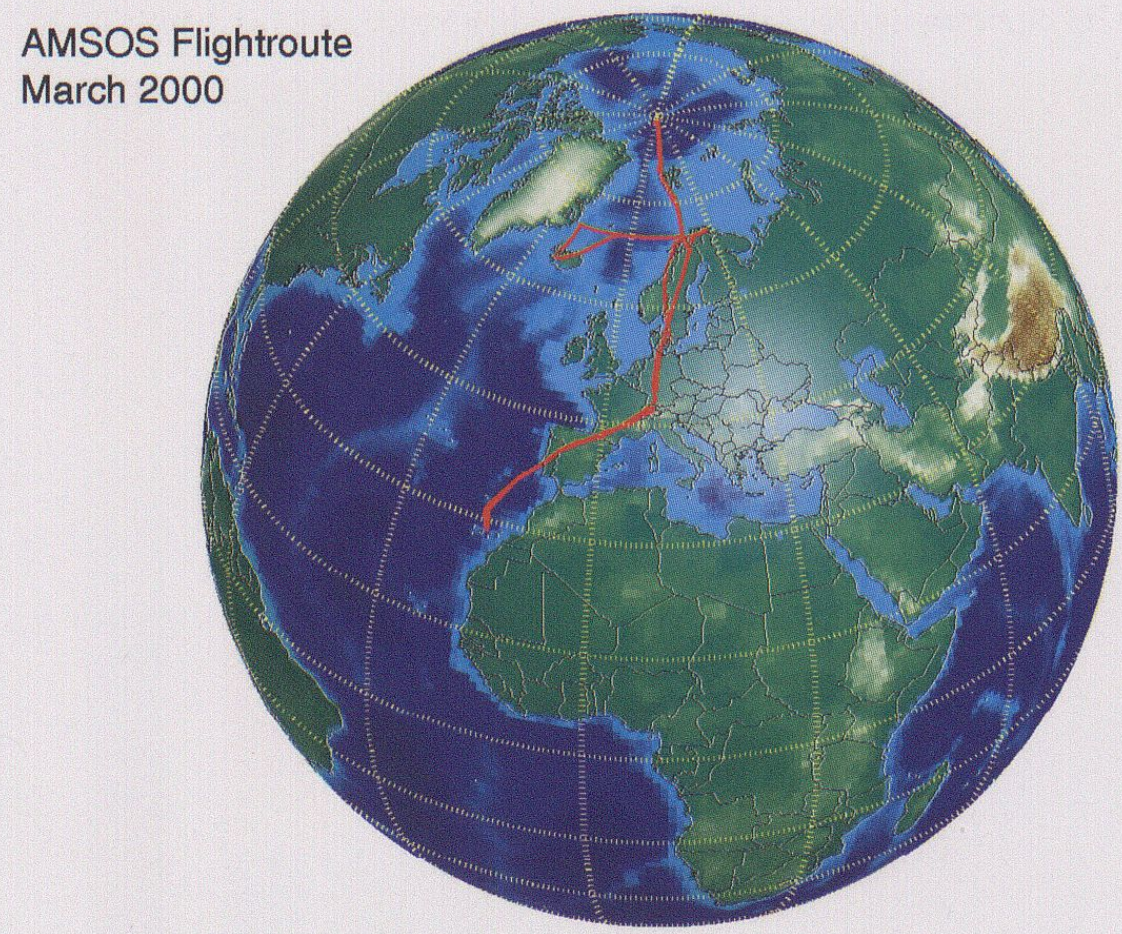

Fig. 2: Flight route of the March 2000 campaign which covered latitudes from subtropics to the north pole. A special flight to Island was performed in order to get data within the polar vortex which was located in this area at the time.

Flugroute der Messkampagne im März. 2000, welche geographische Breiten von den Subtropen bis zum Nordpol abdeckte. Ein Flug wurde speziell nach Island durchgeführt, da zu diesem Zeitpunkt der polare Vortex sein Zentrum in dieser Region hatte.

Route de vol de la campagne de mars 2000 qui couvrait des latitudes s'étendant des régions subtropicales jusqu'au pôle Nord. Un vol au-dessus de l'Islande a été spécialement programmé pour recueillir des données à l'intérieur du vortex polaire qui se trouvait alors sur cette région.

observations are necessary. Even if there are more and more satellite observations available it has to be kept in mind that ground based measurements providing high quality ground truth data will be needed for validation purposes also in the future. Ground based sensors and satellite systems will remain complementary.

The aim of the paper is to show that microwave radiometry is a powerful remote sensing technique for the detection not only of the column density of water vapor or liquid water but in addition also of the water vapor profile. Data from microwave radiometers allow the investigation of the atmosphere from the ground to the mesopause thus providing valuable information for atmospheric research. Results from different instruments are given.

\section{Microwave radiometry}

Microwave radiometry is a passive remote sensing technique which detects emission lines of atmospheric constituents. For a review of the methodology refer to JANSSEN (1993) or KäMPFER (1995), for example. A spectral analysis of the pressure broadened lines allows the retrieval of the altitude profile of the species under investigation over the height range of typically $20 \mathrm{~km}$ to $70 \mathrm{~km}$, which corresponds to altitudes from the lower stratosphere to the mesopause. As a direct detection of the spectral features in the microwave region is technically not possible, with the exception of frequencies below approx. $20 \mathrm{GHz}$, microwave radiometers operate in the so called heterodyne mode. In this mode, the incoming high frequency signal from the atmosphere is superposed with a highly stable signal from a local oscillator in a non linear element, a so-called mixer, thus transforming the complete spectral information to an intermediate frequency where sufficient amplification and spectral analysis is possible. Spectral analysis typically is performed in an acousto optical spectrometer where the microwave frequencies are converted to ultrasonic waves that disperse a monochromatic light beam onto an array of visible 


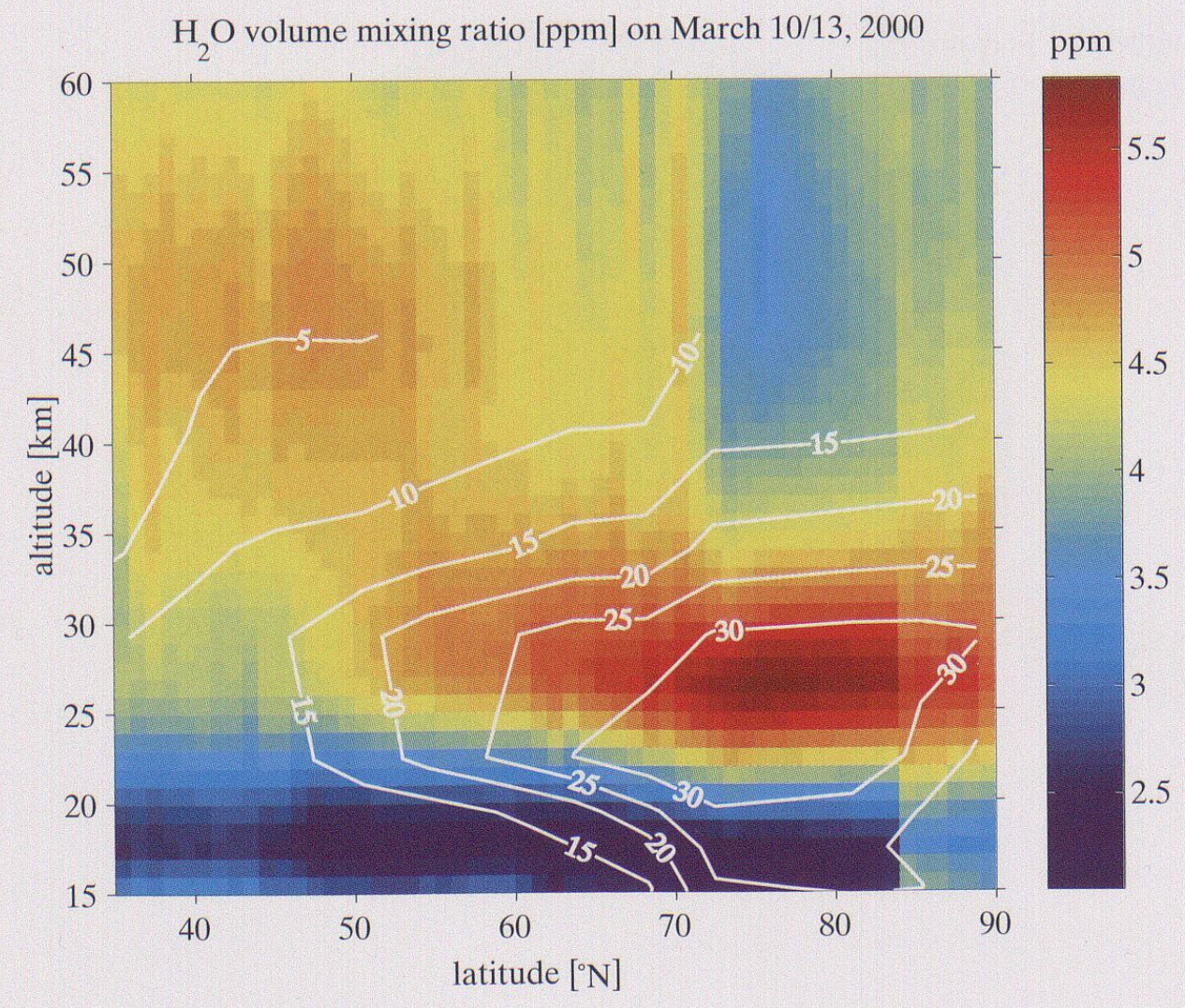

Fig. 3: Latitude-altitude cross sections of water vapor mixing ratio in $\mathrm{ppm}$ with superposed values of potential vorticity.

Mischungsverhältnis von Wasserdampf als Funktion der Höhe und der geographischen Breite. Zusätzlich eingezeichnet sind Werte gleicher potentieller Wirbelstärke.

Coupe verticale et longitudinale du rapport de mélange de la vapeur d'eau en ppm, en tant que fonction d'altitude et de largeur géographique. Sont en outre mentionnées des valeurs ayant le même poids potentiel.

light detectors. In order to minimize the noise contribution of the receiver, such instruments are usually cooled to cryogenic temperatures. The most sophisticated ones operate superconducting junctions as mixing devices requiring cooling to liquid helium temperatures. During the last few years instruments for the detection of transition lines of atmospheric constituents have been developed at the Institute of Applied Physics, IAP, University of Berne and were successful in measuring spectra of $\mathrm{O}_{3}, \mathrm{H}_{2} \mathrm{O}, \mathrm{H}_{2} \mathrm{O}^{18}, \mathrm{ClO}, \mathrm{HCl}$, as well as CO (e.g. KäMPFER 1995; Jost et al. 1996; MAIER et al. 2001; INGOLD et al. 1998; Gerber et al. 2000). Radiometers are operated from the ground, from aircraft (e.g. Peter 1998) and have also been flown on the Space Shuttle (e.g. Aellig et al. 1996; Feist et al. 2000).

\section{Results}

\subsection{Aircraft measurements}

For several years, our institute has provided measurements of water vapor in the middle atmosphere with an airborne microwave radiometer called AMSOS (Air- borne Millimeter and Submillimeter Spectrometer). This radiometer observes a strong water vapor emission line at $183 \mathrm{GHz}$ which is ideal for these airborne measurements. A typical campaign takes about one week and covers almost all of the northern latitudes from the tropics to the arctic. Typical spectra measurements are shown in Figure 1, whereas Figure 2 shows the flight route for the campaign in spring 2000 which led up to the north pole and allowed measurements of the water vapor distribution at the pole for the first time. Figure 3 shows the latitudinal distribution of water vapor with superimposed values of the potential vorticity. The edge of the polar vortex is clearly visible in the altitude profiles of stratospheric water vapor that we retrieved from our spectra. High values of water vapor inside the vortex indicated a strong downward movement of airmasses over an extended period of time during the winter of 1999/2000.

Analysis of data from different seasons indicate that the state of the atmosphere changes drastically between these periods, especially at high latitudes. Measurements taken in winter and spring show a completely 


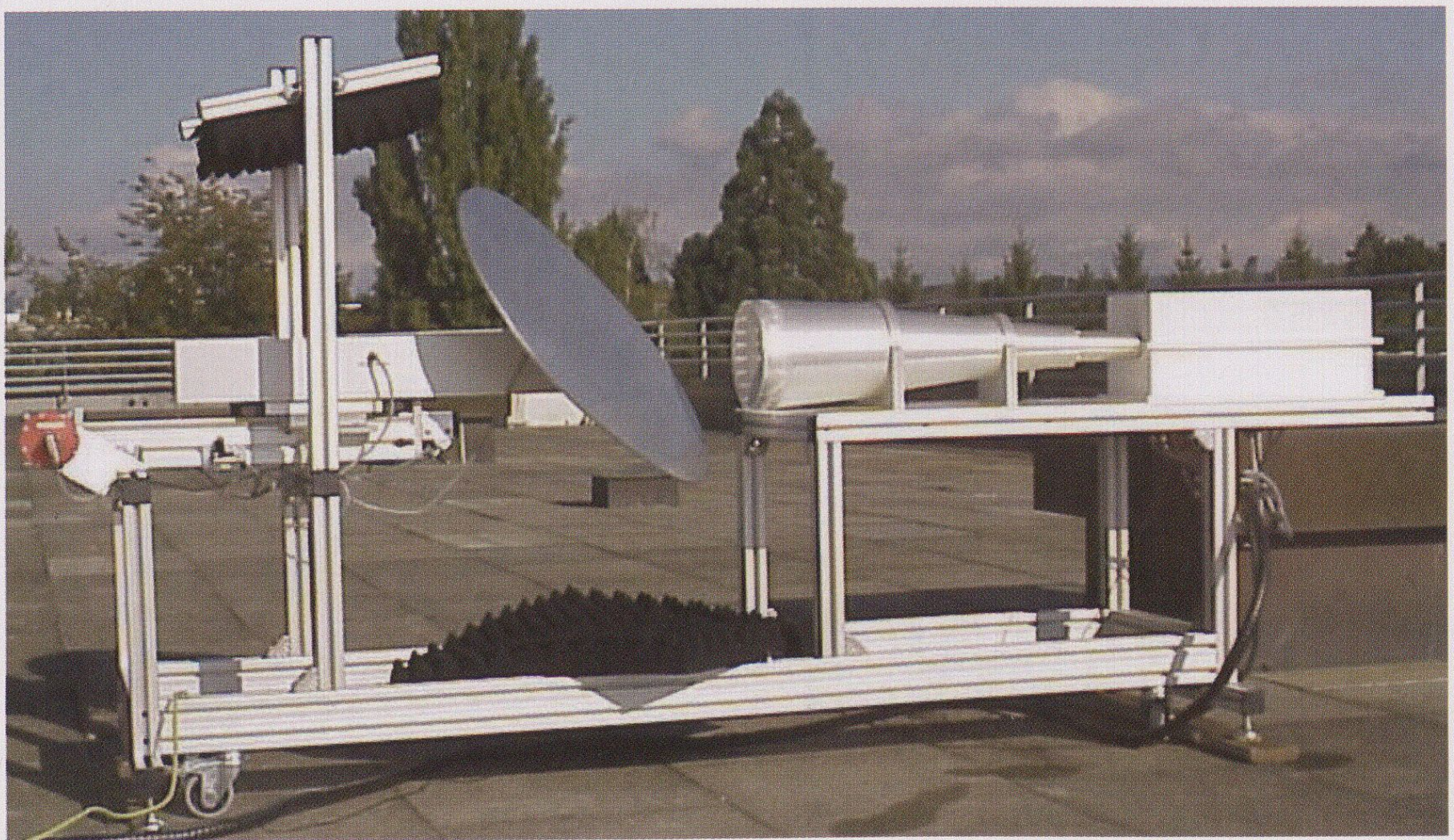

Fig. 4: MIAWARA, Middle Atmospheric Water Radiometer on the roof of the Institute of Applied Physics (IAP), University of Berne, operating at $22 \mathrm{GHz}$.

MIAWARA, Middle Atmospheric Water Radiometer, das bei einer Frequenz von 22 GHz misst, auf dem Dach des Institutes für Angewandte Physik (IAP) der Universität Bern.

MIAWARA, radiomètre mesurant la vapeur d'eau dans la moyenne atmosphère, à une fréquence de $22 \mathrm{GHz}$, sur le toit de l'IAP, Université de Berne.

Photo: B. Deuber

different picture than those taken during summer. Summer profiles show an almost climatological distribution of water vapor with a maximum at high altitudes that varies only slightly with latitude, while winter and spring profiles show a stronger maximum at much lower altitudes in polar regions, typically with very low water vapor values above it. While the pattern in the summer profiles can be explained with slow upward motion and textbook atmospheric chemistry, the winter pattern in the arctic is much more complex. It suggests that strong dynamical processes have transported water vapor from high altitudes downward inside a well-isolated polar vortex.

\subsection{Measurements from the Jungfraujoch}

In addition to the flights, the AMSOS instrument for the first time was placed on the high Alpine research station Jungfraujoch during the winter season when the atmosphere was sufficiently dry enough for water vapor to be measured at this frequency and latitude (Siegenthaler 2001). Data from AMSOS from the Jungfraujoch have also been used for the determina- tion of the isotope ratio of $\mathrm{H}_{2} \mathrm{O}^{18}$ to normal $\mathrm{H}_{2} \mathrm{O}$. An increased interest in isotopic studies of atmospheric constituents can be observed over the last few years. Isotopic composition can be used to deduce information about a species' chemical and/or physical history. Research on the isotopic composition of water vapor can help to determine whether it has been transported into the stratosphere from the troposphere or whether it originates from stratospheric chemical processes. With the tropopause acting as a cold trap, the stratosphere is generally very dry, featuring a water vapor content in the order of $4-6$ ppmv maximum. Throughout the tropo-sphere this value increases rapidly up to a value in the order of 1000 ppmv at our observation altitude of 3'500 meters. We analyzed EMCOR (European Minor Constituent Radiometer) data of the $203.407520 \mathrm{GHz}$ rotational transition line of $\mathrm{H}_{2} \mathrm{O}^{18}$ from the period of December 15, 1999 to January 20, 2000. A description of the instrument which has been installed at our institute can be found in MAIER (2001). In addition, we used data for $\mathrm{H}_{2} \mathrm{O}$ from AMSOS observed at the same location. The retrieved data have 


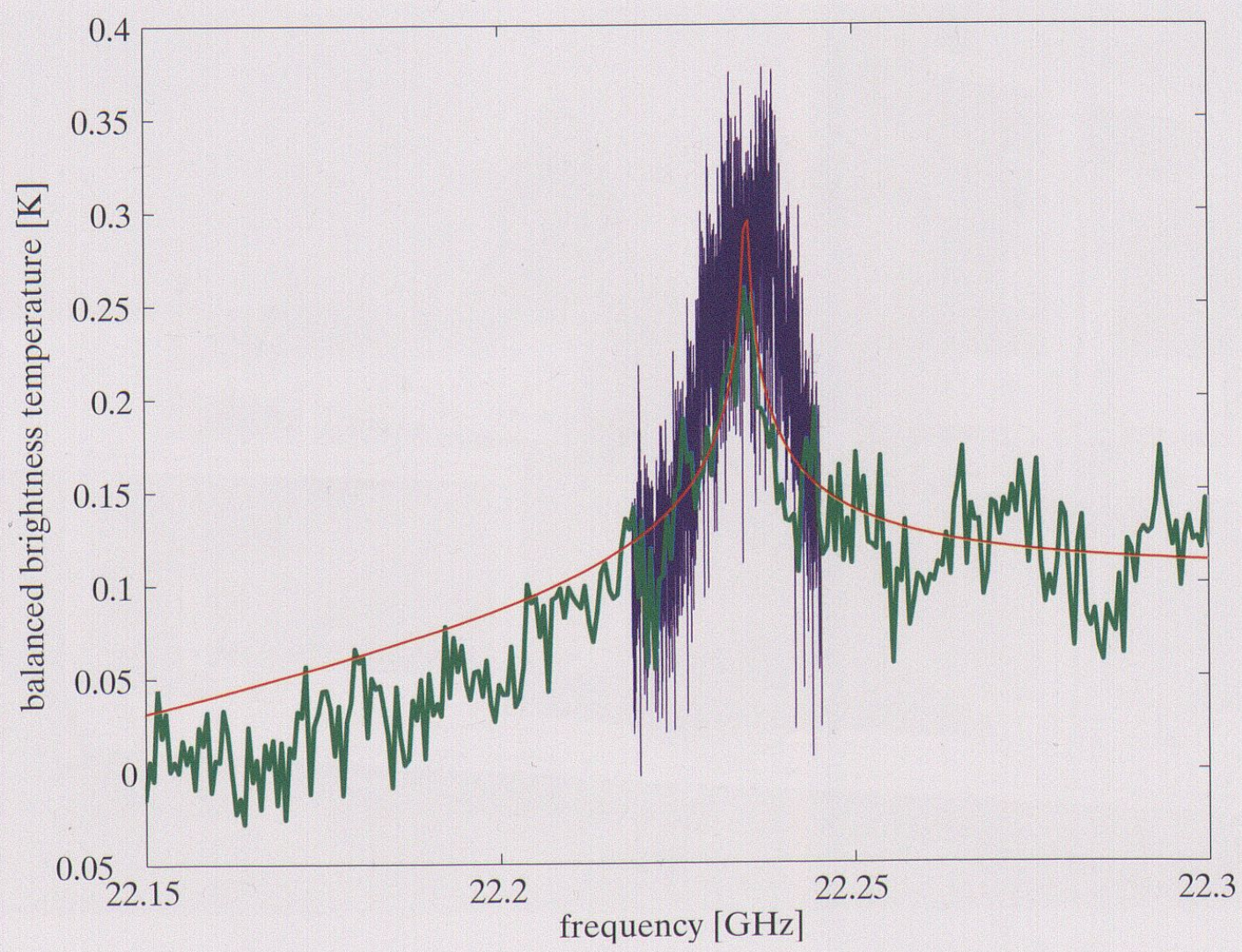

Fig. 5: Spectrum of the water vapor transition line at $22 \mathrm{GHz}$ with an extremely high resolution of $15 \mathrm{kHz}$ at line center thus providing the possibility to retrieve the profile of water vapor up to the mesopause.

Spektrum der Wasserdampflinie bei $22 \mathrm{GHz}$, gemessen mit einer extrem hohen Auflösung von $15 \mathrm{kHz}$, was erlaubt, die Verteilung von Wasserdampf auch in der Mesosphäre zu bestimmen.

Spectre de la ligne de transition de la vapeur d'eau à $22 \mathrm{GHz}$, mesuré avec une résolution extrême de $15 \mathrm{kHz}$, permettant ainsi de déduire le profil de distribution de la vapeur d'eau jusqu'à la mésopause.

been validated with $\mathrm{H}_{2} \mathrm{O}$ profiles from the POAM satellite experiment. The derived isotopic ratio is in accordance with the results from RinSLAND et al. (1991), which means close to SMOW (Standard Mean Ocean Water) but with a notable tendency to negative values at $30-35 \mathrm{~km}$ and $50-55 \mathrm{~km}$ altitude.

\subsection{A new instrument for water vapor in the middle atmosphere}

In order to measure middle atmospheric water vapor also during less favorable conditions and particularly from low altitudes, a different spectral line has to be used. The transition at $22.235 \mathrm{GHz}$ has an opacity which is sufficiently weak to be used from an observation site such as Berne (550 $\mathrm{m}$ a.s.l.). An instrument has been built based on a concept which minimizes optical components in order to reduce any internal reflections leading to baseline effects. The radiometer has an outstanding system temperature of $160 \mathrm{~K}$ in single sideband mode (Deuber 2001; Deuber et al. 2002). An impression of the instrument is given in Figure 4.
First spectra of the water vapor transition line with an extremely high spectral resolution of $15 \mathrm{kHz}$ is given in Figure 5. This high spectral resolution will allow the retrieval of the altitude profile of water vapor up to the mesopause thus giving insight into processes which are poorely understood.

\subsection{Tropospheric water vapor}

In contrast to the stratosphere where water vapor is a trace gas, water vapor in the troposphere is found in abundance and is a highly variable factor contributing to weather and climate. In order to determine the columnar water vapor distribution in the troposphere along with a temperature profile, we used ASMUWARA (All Sky Multi Wavelength Radiometer) which has the unique advantage of allowing the observation of the parameters of interest over the whole sky by means of scanning in azimuth and elevation. Local inhomogeneities can thus be easily detected (MARTIN 2003). In addition to several channels in the microwave region, the instrument has an infrared sensor which 


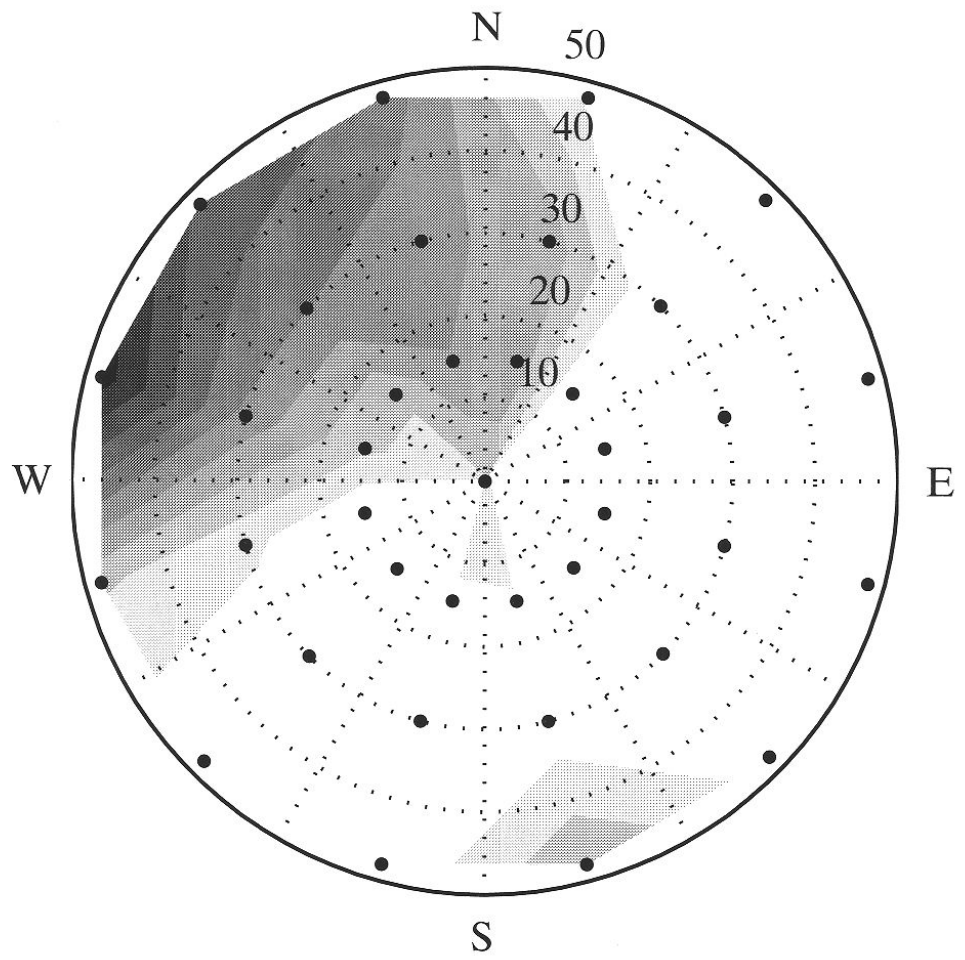

Fig. 6: The integrated liquid water content (ILW) of the atmosphere over Berne on $16^{\text {th }}$ April 2002. The angle in the polar diagrams represents the azimuth and the radius represents the zenith angle of the observation direction. White corresponds to $0 \mathrm{~mm}$ and black to $0.5 \mathrm{~mm}$ of ILW. Large black dots indicate measurements.

Der integrierte Flüssigwassergehalt der Atmosphäre über Bern für den 16. April 2002. Der Radius im Polardiagramm entspricht dem Zenithwinkel. Weiss entspricht $0 \mathrm{~mm}$ und schwarz $0.5 \mathrm{~mm}$ Flüssigwasser. Die schwarzen Punkte geben die Messstellen an.

Valeur intégrée du contenu en eau liquide (CEL) de l'atmosphère au-dessus de Berne, le 16 avril 2002. L'angle du diagramme polaire indique l'azimut et le rayon indique l'angle zénithal d'observation. La courbe blanche correspond à un CEL de $0 \mathrm{~mm}$, la courbe noire à un CEL de $0.5 \mathrm{~mm}$. Les points de mesure sont représentés par les points noirs.

is used for cloud detection. In addition to allowing the observation of water vapor, this instrument also opens up the possibility to observe cloud liquid water, a parameter which can not be measured, for e.g. with balloon soundings and which thus gives insight into the total water content of a cloud. An example of the two dimensional distribution of the liquid water content of the sky is given in Figure 6. As the time resolution of these maps is a few minutes, they provide insight into the dynamical processes of the atmosphere.

\section{Conclusions}

Microwave remote sensing is an excellent means of studying processes in the atmosphere related to water vapor and liquid water content. The analysis of spectral features allows the investigation of the atmosphere from the troposphere to the mesopause. Further, it delivers information on the column densities of the troposphere. Due to the operation from an aircraft, latitudinal variations of water vapor in the middle atmosphere can be investigated. As the chemical lifetime of water vapor is high, it is possible to study dynamical processes, as was the case within the polar vortex. The distinction of different isotopes might give insight into the origin of water in the middle atmosphere. Phenomena in the troposphere can be accessed with a novel method providing maps of the sky for integrated water vapor and liquid content. Therefore this method is well suited for investigations in climate research as is done within project STARTWAVE of NCCR-climate within Switzerland.

\section{Acknowledgments}

This research was supported by the Swiss National Science Foundation under grant 2000-063793.00 and by NCCR-climate. 


\section{References}

Aellig, C.P., Bacmeister, J., Bevilacqua, R., Daehler, M., Kriebel, D., Pauls, T., Siskind, D., Kämpfer, N., Langen, J., Hartmann, G., Berg, A., Park, J. \& J. Russel (1996): Spaceborne $\mathrm{H}_{2} \mathrm{O}$ observations in the Arctic stratosphere and mesosphere in the spring of 1992. - In: Geophys. Res. Lett., 23, 17: 2325-2328.

Deuber, B. (2001): MIAWARA - Ein MikrowellenRadiometer zur bodengestützten Messung von Wasserdampf in der mittleren Atmosphäre. - Master of Science thesis, Faculty of science, University of Berne.

Deuber, B. , Feist, D.G. \& N. Kämpfer (2002): Ground based measurements of middle atmospheric water vapor using a microwave radiometer. - Sixth European Symposium on Stratospheric Ozone, Gothenborg, September 2002.

Feist, D.G., Aellig, C., Kämpfer, N., Peter, R., Solomon, P., Barrett, J., Zoonematkermani, S., Parrish, A., Hartogh, P., Jarchow, C., Bevilacqua, R., Hartmann, G. \& J. WATERS (2000): Validation of stratospheric ClO measurements from the millimeter-wave atmospheric sounder (MAS). - In: J. Geophys. Res. 105: 9053-9062. Gerber, D., Lezeaux, O. \& N. Kämpfer (2000): Ground based microwave measurements of midlatitude stratospheric $\mathrm{H}_{2} \mathrm{O}^{18}$ and derivation of the isotopic ratio. - In: Proceedings of the Quadrennail Ozone Symposium, Sapporo: 399-400.

Ingold, Th. , Peter, R. \& N. Kämpfer (1998): Weighted mean tropospheric temperature and transmittance determination at mm-wave frequencies for groundbased applications. - In: Radio Science 33, 4: 905- 918. Intergovernmental Panel on Climate Change (IPCC) (2001): Climate Change 2001, the scientific basis. Contribution of working group I to the third assessment report of the Intergovernmental Panel on Climate Change, Cambridge: University Press.

Janssen, M.A. (ed.) (1993): Atmospheric Remote Sensing by Microwave Radiometry. - New York: John Wiley \& Sons.

Jost, H., Kämpfer, N., Lecacheux, A. \& C. Rosolen (1996): Broadband acousto optic spectrometer used as backend for remote sensing of trace gases in the atmosphere. - In: IEEE Transactions on Geoscience and Rem. Sensing 34: 927-935.

KäMPFER, N. (1995): Microwave remote sensing of the atmosphere in Switzerland. - In: Optical Engineering 34, 8: 2413-2424.

KEITH,W.K.(2000): Stratosphere-troposphere exchange: inferences from the isotopic composition of water vapor. - In: J. Geophys. Res. 105 (D12): 15167-15173.

Maier, D., Kämpfer, N., Amacher, W., Wüthrich, M., de la Noe, J., Ricaud, P., Baron, P., Beaudin, G., Viguerie, C., Pardo, J.-R., Gallego, J.D., Barcia, A., Cernicharo, J., Ellison, B., Siddans, R., Matheson, D., Künzi, K., Klein, U., Franke, B., Louhi, J., Mallat, J., Gustafsson, M., RÄIsÄnen, A. \& A. Karpov (2001): EMCOR (European Minor Constituent Radiome- ter): a new millimeter wave receiver for atmospheric research. - In: Int. J. Infrared \& Millim. Waves 22, 11 : 1555- 1575.

Martin, L. (2003): Microwave transmission and emission measurements for tropospheric monitoring. Ph.D thesis, Faculty of science, University of Berne. Mote, Ph. W., Rosenlof, K.H., McIntyre, M.E., Carr, E.S., Gille, J.C., Holton, J.R., Kinnersley, J.S., PumPhrey, H.C., Russell III, J.M. \& J. Waters (1996): An atmospheric tape recorder: The imprint of tropical tropopause temperatures on stratospheric water vapor. - In: J. Geophys. Res. 101 (D2): 3989-4006.

Nedoluha, G.E., Bevilacqua, R.M., Gomez, R.M., Waltman, W.B., Hicks, B., Thacker, D.L., Russell, J.M., Abrams, M., Pumphrey, H.C. \& B. Connor (1997): A comparative study of mesospheric water vapor measurements from the ground-based water vapor millimeter-wave spectrometer and space-based instruments. - In: J. Geophys. Res. 102 (D14): 16647-16661.

Nedoluha, G.E., Bevilacqua, R.M., Gomez, R.M., Siskind, D.E., Hicks, B., Russell, J.M. \& B. Connor (1998): Increases in middle atmospheric water vapor as observed by the Halogen Occultation Experiment and the ground-based water vapor millimeter-wave spectrometer from 1991-1997. - In: J. Geophys. Res. 103 (D3): 3531-3543.

Nedoluha, G.E., Bevilacqua, R.M., Gomez, R.M., Hicks, B. \& J.M. Russell III (1999): Measurements of middle atmospheric water vapor from low latitudes and midlatitudes in the northern hemisphere. - In: J. Geophys. Res. 104 (D16): 19257-19266.

Ovarlez, J., van Velthoven, P. \& H. Schlager (1999): Water vapor measurements from the troposphere to the lowermost stratosphere: some signatures of troposphere to stratosphere exchanges. - In: J. Geophys. Res. 104 (D14): 16973-16978.

Rinsland, C.P., Gunson, M.R., Foster, J.C., Toth, R.A., FARMer, C.B. \& R. ZANDER (1991): Stratospheric Profiles of Heavy Water Isotopes and CH3D From Analysis of the ATMOS Spacelab 3 Infrared Solar Spectra. - In: J. Geophys. Res. 96: 1057-1068.

Seele, C. \& P. Hartogh (1999): Water vapor of the polar middle atmosphere: Annual variation and summer mesospheric conditions as observed by ground based microwave spectroscopy. - In: Geophys. Res. Lett. 26, 11: 1517- 1520 .

SHEPHERD, T. (2000): On the role of the stratosphere in the climate system. $-=$ SPARC newsletter No. 14 .

Siegenthaler, A., Lezeaux, O., Feist, D. \& N. KÄmpfer (2001): First water vapor measurements at $183 \mathrm{GHz}$ from the high alpine station Jungfraujoch. - In: IEEE, Trans. On Geosc. And Remote Sensing 39, 9: 2084-2086.

SPARC (2000): SPARC Assessment of Upper Tropospheric and Stratospheric Water Vapor, WCRP-113. = SPARC Report No. 2.

Stone, E.M., PAn, L., SAndor, B.J., Read, W.G. \& J.W. WATERS (2000): Spatial distributions of upper tropo- 
spheric water vapor measurements from UARS microwave limb sounder. - In: J. Geophys. Res. 105 (D10): 12149-12161.

Summers, M.E., Conway, R.R., Siskind, D.E., Stevens, M.H., Offermann, D., Riese, M., Preusse, P., Strobel, D.F. \& J.M. RusSELL III (1997): Implications of satellite $\mathrm{OH}$ observations for middle atmospheric $\mathrm{H}_{2} \mathrm{O}$ and ozone. - In: Science 277: 1967-1970.

Summers, M.E. \& D.E. Siskind (1999): Surface recombination of $\mathrm{O}$ and $\mathrm{H}_{2}$ on meteoric dust as a source of mesospheric water vapor. - In: Geophys. Res. Lett. 26, 13: 1837-1840.

Westwater, E.R., Stankov, B.B., Han, Y., Shaw, J.A., Long, C.N., Lesht, B.M. \& J. Shannahoff (2000): Comparison of microwave radiometers and radiosondes during the Nauru-99 experiment. - Proc. IEEE International Geoscience and Remote Sensing Symposium (IGARSS) 2000, Honolulu, Hawaii, July, 24-28.

World Meteorological Organization (WMO) (1998): Scientific assessment of ozone depletion: 1998. - Global Ozone Research and Monitoring Project, Report No. 44.

\section{Summary: Microwave Remote Sensing of Water Vapor in the Atmosphere}

Water vapor in the atmosphere plays a crucial role in climate and in atmospheric processes. Due to its long chemical lifetime it can be used as a tracer for investigations of dynamical processes in the middle atmosphere. Microwave radiometry is one of the few remote sensing methods which is capable of inferring information on the water vapor content of the troposphere to the mesosphere, however with a different altitude resolution. Different microwave radiometers that can be operated from the ground and from an airborne platform have been built at the Institute of Applied Physics, University of Berne. The paper presents the method of microwave remote sensing and gives an overview of recently achieved results with regard to water vapor distribution as a function of altitude and latitude. First results of an imaging radiometer for the two dimensional distribution of liquid water is presented.

\section{Zusammenfassung: Mikrowellen-Fernerkundung von Wasserdampf in der Atmosphäre}

Die Verteilung von Wasserdampf in der Atmosphäre spielt eine substantielle Rolle für das Klima und für atmosphärische Prozesse. Dank der langen chemischen Lebenszeit in der mittleren Atmosphäre, kann Wasserdampf auch als Tracer für die Untersuchung dynamischer Prozesse verwendet werden. Mikrowellen-Radiometrie ist eine Fernerkundungsmethode, die Information über die Verteilung von Wasserdampf von der Troposphäre bis in die Mesosphäre liefern kann. Allerdings ist die Höhenauflösung für die verschiedenen Regionen unterschiedlich. Am Institut für Angewandte Physik der Universität Bern wurden verschiedene Mikrowellen-
Radiometer entwickelt, die vom Boden, aber auch von einem Flugzeug aus eingesetzt werden. Die Publikation stellt die Fernerkundungsmethode vor und gibt eine Übersicht über kürzlich erlangte Resultate über die Verteilung von Wasserdampf als Funktion der Höhe, aber auch in Abhängigkeit von der geographischen Breite, von den Subtropen bis zum Nordpol. Es werden auch erste Resultate eines abbildenden Sensors für die Flüssigwasser-Verteilung vorgestellt.

\section{Résumé: La sensibilité à distance de la radiométrie micro-ondes à la vapeur d'eau dans l'atmosphère} La vapeur d'eau joue un rôle crucial dans les processus climatiques et atmosphériques. Grâce à son temps de vie chimique très long, cette molécule peut être utilisée comme traceur pour l'étude de processus dynamiques dans la moyenne atmosphère. La radiométrie micro-ondes est une technique de télédétection passive permettant d'interférer l'information sur le contenu en vapeur d'eau de l'atmosphère de la troposphère jusqu'à la mésosphère, avec une résolution verticale dépendant des régions considérées. Plusieurs radiomètres micro-ondes ont été construits à l'Institut de Physique Appliquée de l'Université de Berne, et sont utilisés au sol et à bord d'un avion. L'article présente la technique de la radiométrie micro-ondes et donne un survol des résultats récents obtenus sur la distribution de la vapeur d'eau en fonction de l'altitude et de la latitude, depuis la région sub-tropicale jusqu'au Pôle Nord. Sont également présentés les premiers résultats d'un nouveau radiomètre permettant de mesurer depuis le sol la distribution de la vapeur d'eau dans deux dimensions.

\section{Teaching in Geography - pertinent questions}

- Why is water vapor interesting?

- How is it possible to measure the altitude distribution of water vapor without being in situ?

- What are the characteristics of MIAWARA?

What were the results of the different methods?

- Where can I find out more about research in this area?

Visit the webpage http:/www.iapmw.unibe.ch/research/

Prof. Dr. Niklaus Kämpfer, Dipl.-Phys. Beat Deuber, Dr. Dietrich Feist, Dipl.-Phys. Daniel Gerber, Prof. Dr. Christian Mätzler, Dr. Lorenz Martin, Dr. June Morland, Dipl.-Ing. Vladimir Vasic, Institute of Applied Physics, University of Berne, Sidlerstrasse 5, CH-3012 Berne. http://www.iap.unibe.ch

Manuskripteingang/received/manuscrit entré le 11.7.2002

Annahme zum Druck/accepted for publication/accepté pour l'impression: 5.6 .2003 